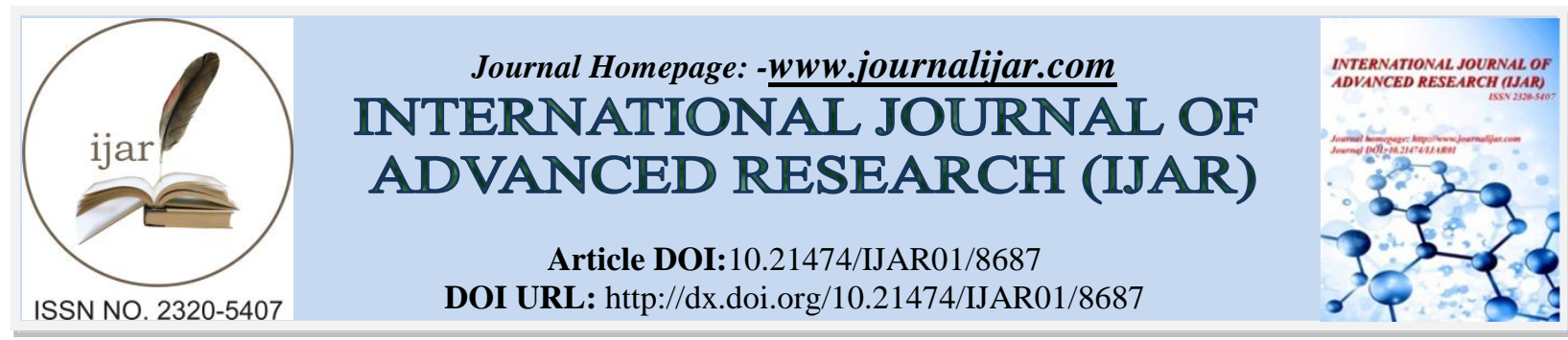

RESEARCH ARTICLE

\title{
EFFECT OF IPOMOEA PES-CAPRAE (LINN.) R. BR. STEM AND ROOT EXTRACTS ON DIFFERENT CLINICAL BACTERIAL ISOLATES.
}

\author{
Sana Eijaz ${ }^{1}$, Muneeba Khan², Anjum Perveen ${ }^{2}$, Shazia Mansuri², Muhammad Nadir ${ }^{3,4}$ and Muneera \\ Naz Baloch ${ }^{1}$. \\ 1. Department of Microbiology, University of Karachi, Karachi, Pakistan. \\ 2. Center for Plant Conservation, University of Karachi, Karachi, Pakistan. \\ 3. Department of Chemistry, University of Karachi, 75270, Karachi, Pakistan. \\ 4. Department of Chemistry, Government Degree Boys College, Sector 5/L, New Karachi, 75850, \\ Karachi, Pakistan.
}

\section{Manuscript Info}

\section{Manuscript History}

Received: 13 January 2019

Final Accepted: 15 February 2019

Published: March 2019

\section{Key words:-}

Ipomoea pes-caprae (Linn.) R. Br., traditional medicine, clinical bacterial isolates, stem and root extract.

\begin{abstract}
The aim of the present study was to investigate the antibacterial activity of chloroform, ethyl acetate, hexane and methanol extracts of Ipomoea pes-caprae (Linn.) R. Br. extracts of roots and stem of plant Ipomoea pes-caprae (Linn.) R. Br. The extracts were tested against different clinical bacterial isolates and the antibacterial activity was performed by using well-plate method. The results demonstrated that the methanol extract of Ipomoea pes-caprae stem and ethyl acetate extract of Ipomoea pes-caprae root exhibit strong antibacterial activity. Our results showed that this plant have observable therapeutic effects on potential infectious agents and can be used as an alternate to conventional medicines.
\end{abstract}

Copy Right, IJAR, 2019,. All rights reserved.

\section{Introduction:-}

The traditional medicine comprises several herbal and non-herbal constituents and it is hypothesized that they have potential to act on a number of targets through various mechanisms (Tiwari and Raos, 2002). It is observed that the herbal treatment options are associated with a small number of side effects in contrast to conventional ones (Sharma et al., 2008). A critical problem coupled with the integration of medicinal herbs in advanced clinical practices is the inadequate amount of clinical and scientific data which suggested their safety and efficacy (Modak et al., 2007).

Indiscriminate use of antibiotics is a major factor responsible for the emergence and dissemination of multidrug resistance strains of microorganisms. This urges the researchers to move their attention towards herbal products research (Khan et al., 2009). The use of plant-based therapies is increasing in both underdeveloped and developed countries. As they are natural products, having affordable prices, less toxicity, no deleterious side effects, are simply biodegradable and are easily accessible (Aruna and Nandakishore, 2014).

Humans are the important host of a number of bacterial pathogens, cause several infectious diseases. Proteus mirabilis has an ability to cause empyema and osteomyelitis (Bahashwan and Shafay, 2013). Shigella dysenteriae cause serious infections because of the production of shiga toxin (Omololu-Aso et al., 2017). Klebsiella cause meningitis, bacteremia, urinary tract infections and pneumonia (Kumar et al., 2016; Jayaraj et al., 2014). According to the literature, about 250,000 people died per year globally because of the typhoid fever which is caused by 
Salmonella typhi (Saleh et al., 2014). Salmonella typhi para A cause enteric fever usually known as paratyphoid (Naveed and Ahmed, 2016). Escherichia coli is associated with urinary tract infections mainly cystitis (Kariuki et al., 2007) and Enterococcus faecalis is now ranked among the top three nosocomial bacterial pathogens (Kayaoglu and Orstavik, 2004). Pseudomonas aeruginosa is responsible for causing pneumonia and also severely affects the lungs of patients suffering from cystic fibrosis (Debarbieux et al., 2010). Staphylococcus epidermidis can cause cojunctivitis and endophthalmitis (Dave et al., 2011). Staphylococcus saprophyticus is a causative agent of urinary tract infections (UTIs) in young and adult females (Raz et al., 2005; Widerstrom et al., 2012). Methicillin resistant Staphylococcus aureus (MRSA) cause infections associated with high mortality rate including nasal infections (Parasa et al., 2011; Chao et al., 2008).

The genus Ipomoea belongs to the family Convolvulaceae. It is the largest genus with about 500 species distributed throughout the tropics and subtropics of both the hemispheres. Ipomoea pes-caprae (Linn.) R. Br. is a climber with its stem trailing and rooting at the nodes and the stem is usually glabrous and hard. This is a halophytic plant found abundantly in the coastal areas. Its common name is "Samudraphen". The plant is used in medicine and the leaves are applied externally in rheumatism and colic (Austin and Ghazanfar, 1979).

In this study, the antimicrobial effect of different extracts was observed on various gram positive and gram negative clinical bacterial isolates including Escherichia coli, Proteus mirabilis, Pseudomonas aeruginosa, Salmonella typhi, Salmonella typhi para A, Klebsiella pneumoniae, Citrobacter species, Enterobacter species, Methicillin-resistant Staphylococcus aureus (MRSA), Shigella dysenteriae, Streptococcus fecalis, Staphylococcus epidermidis and Staphylococcus saprophyticus.

\section{Materials and Method:-}

\section{Collection of Herbs:}

The root and stem parts of Ipomoea pes-caprae (Linn.) R. Br. were collected from coastal area of Karachi and the voucher specimen has been submitted in the Karachi university herbarium (G.H.no.86616). The plant was identified by the taxonomist in Herbarium, Center for Plant Conservation which is situated in the University of Karachi, Karachi.

\section{Collection of clinical bacterial isolates:}

The clinical bacterial isolates were collected from patients sample and identified by using the standard microscopical, colonial and biochemical characteristics. The bacterial isolates were collected from a diagnostic laboratory.

\section{Preparation of Herbal Extracts:}

For the preparation of herbal extracts, the roots and stem parts of Ipomoea pes-caprae (Linn.) R. Br. were washed, dried, crushed and grinded to convert into powdered form. The soxhlet apparatus was used to make different extracts of the collected plant. 15 grams of powdered plant material was weighed and wrapped in whatsman 41 filter paper. The plant material was placed inside the extraction tube, over which a condenser was fixed. The soxhlet apparatus was connected to a distillation flask and a chiller which was set at temperature $5^{\circ} \mathrm{C} .150 \mathrm{ml}$ of respective solvent i.e. hexane, chloroform, ethyl acetate and methanol was poured respectively in the distillation flask placed on a heating mantle. The temperature was adjusted in accordance with the solvent used $\left(30^{\circ} \mathrm{C}-40^{\circ} \mathrm{C}\right)$. The extraction procedure was continued for about 14-15 hours. The extract was then transferred to a round bottom flask to concentrate by using BUCHI Rota-vapour R-200. The flask containing the extract sample was submerged in a water bath set to the temperature $40^{\circ} \mathrm{C}$. The concentrated extract was partitioned in the extract tube and left opened for the removal of any residual solvent. The dried form of extract was kept at $4^{\circ} \mathrm{C}$ for experimental procedures (Redfern $e t$ al., 2014).

\section{Effect of plant extracts on clinical bacterial isolates:}

For the preparation of plant extracts, different solvents were used including methanol, ethyl acetate, hexane and chloroform. DMSO was used to make different concentrations of four types of extracts i.e. $250 \mu \mathrm{g}, 500 \mu \mathrm{g}, 750 \mu \mathrm{g}$, $1000 \mu \mathrm{g}, 5000 \mu \mathrm{g}$. Extract concentrations were selected after performing MIC assay.

\section{Preparation of lawns:}

Mueller Hinton agar was used to see the antibacterial activity by performing well-diffusion technique. 0.5 McFarland's index was prepared to get the inoculum size of $1.5 \times 10^{8} \mathrm{CFU} / \mathrm{ml}$ (Coyle, 2005). $0.1 \mathrm{ml}$ was added and 
lawns were prepared by the help of spreader. After certain period of time, wells were made on each plate with the help of a borer. $50 \mu \mathrm{l}$ of each extract concentrations i.e. $250 \mu \mathrm{g}, 500 \mu \mathrm{g}, 750 \mu \mathrm{g}, 1000 \mu \mathrm{g}, 5000 \mu \mathrm{g}$, was added in the respective wells. $50 \mu \mathrm{l}$ of DMSO was added in one well as a negative control and the plates were incubated for 24 hours.

\section{Measurement of zone of inhibition:}

After incubation, the plates were observed for the zone of inhibition around the wells and the diameter was measured in millimetres ( $\mathrm{mm})$.

\section{Statistical analysis:-}

Statistical analysis was performed by using the software IBM SPSS Statistics 23. One way analysis of variance (ANOVA) followed by Bonferroni post hoc test and student's t-test were performed to compare the groups with level of confidence $P<0.05$; (where $*=P<0.05$, ** $=\mathrm{P}<0.01$, *** $=\mathrm{P}<0.001$ ). Data are presented as mean $\pm \mathrm{SEM}$.

\section{Results:-}

In this study, the antimicrobial effect of various extracts was observed on thirteen clinical bacterial isolates including Escherichia coli, Proteus mirabilis, Pseudomonas aeruginosa, Salmonella typhi, Salmonella typhi para A, Klebsiella pneumoniae, Citrobacter species, Enterobacter species, Methicillin-resistant Staphylococcus aureus (MRSA), Shigella dysenteriae, Streptococcus fecalis, Staphylococcus epidermidis and Staphylococcus saprophyticus. We used clinical isolates of bacteria to ensure that these strains are pathogenic.

All the clinical bacterial isolates were treated with five concentrations of hexane extract of Ipomoea pes-caprae stem i.e. $250 \mu \mathrm{g}, 500 \mu \mathrm{g}, 750 \mu \mathrm{g}, 1000 \mu \mathrm{g}$ and $5000 \mu \mathrm{g}$ (Fig. 1a). In case of Salmonella typhi, Proteus mirabilis, Pseudomonas aeruginosa, Citrobacter species, Salmonella typhi para A, Staphylococcus saprophyticus, Enterobacter species, Klebsiella pneumoniae and Methicillin-resistant Staphylococcus aureus (MRSA), statistically significant and large zones of inhibition were produced as compared to the control, showing that this extract possesses high activity against these organisms ( $\mathrm{p}<0.001 * * *)$. No zone of inhibition was found at any concentration of the extract when Shigella dysenteriae, Streptococcus fecalis and Escherichia coli were exposed to this treatment.

In the same manner, when bacterial isolates were treated with different concentrations of chloroform extract of Ipomoea pes-caprae stem (Fig. 1b), it was observed that clear zones of inhibition were present around all the wells of Salmonella typhi, Proteus mirabilis, Pseudomonas aeruginosa, Citrobacter species, Enterobacter species, Klebsiella pneumoniae and Salmonella typhi para A. This shows that these organisms are highly sensitive against the chloroform extract while Staphylococcus saprophyticus and Shigella dysenteriae were insensitive to the lower concentrations of the extract. Only one organism i.e. Methicillin-resistant Staphylococcus aureus (MRSA), showed non-significant results as small zones were produced. This extract showed no activity against Streptococcus fecalis, Escherichia coli and Staphylococcus epidermidis.

When we analyzed the effect of ethyl acetate extract of Ipomoea pes-caprae stem (Fig. 1c) on the selected clinical bacterial isolates, the results indicated that this extract exhibits significant antibacterial activity against Salmonella typhi, Proteus mirabilis, Pseudomonas aeruginosa, Citrobacter species, Enterobacter species, Klebsiella pneumoniae, Salmonella typhi para A, Staphylococcus epidermidis, Methicillin-resistant Staphylococcus aureus (MRSA), Shigella dysenteriae and Escherichia coli as significant zones were appeared ( $\mathrm{p}<0.001 * * *)$. In case of Staphylococcus saprophyticus, non-significant zones were found. Streptococcus fecalis was able to survive at all the concentrations of the extract. The control did not show any antibacterial activity.

The results of methanol extract of Ipomoea pes-caprae stem (Fig. 1d) showed that this extract significantly (p $\left.<0.001^{* *}\right)$ affect the growth of Salmonella typhi, Pseudomonas aeruginosa, Citrobacter species, Enterobacter species, Klebsiella pneumoniae, Salmonella typhi para A, Staphylococcus saprophyticus, Shigella dysenteriae and Methicillin-resistant Staphylococcus aureus (MRSA). This extract showed non-significant activity against Proteus mirabilis and Staphylococcus epidermidis. Escherichia coli and Streptococcus fecalis remained insensitive to all the concentrations as no zone of inhibition was found.

To evaluate the effect of hexane extract of Ipomoea pes-caprae root (Fig. 2a), same method was followed. When the clinical bacterial isolates were treated with five different concentrations of the extract, i.e. $250 \mu \mathrm{g}, 500 \mu \mathrm{g}, 750 \mu \mathrm{g}$, 
$1000 \mu \mathrm{g}$ and $5000 \mu \mathrm{g}$, it was observed that Proteus mirabilis, Citrobacter species, Salmonella typhi para A, Pseudomonas aeruginosa, Enterobacter species and Klebsiella pneumonia were significantly sensitive to this extract $(\mathrm{p}<0.001 * * *)$. Non-significant zones were produced in case of Salmonella typhi. However, this extract was unable to inhibit the growth of Staphylococcus saprophyticus, Methicillin-resistant Staphylococcus aureus (MRSA), Shigella dysenteriae, Streptococcus fecalis and Escherichia coli.

Moreover, when the chloroform extract of Ipomoea pes-caprae root (Fig. 2b) was examined, it was observed that few organisms i.e. Salmonella typhi, Proteus mirabilis, Citrobacter and Salmonella typhi para A were significantly inhibited by all the concentrations of this extract (p <0.001***). Pseudomonas aeruginosa, Klebsiella pneumoniae, Enterobacter species, Staphylococcus saprophyticus, Methicillin-resistant Staphylococcus aureus (MRSA), Shigella dysenteriae, Staphylococcus epidermidis, Streptococcus fecalis and Escherichia coli showed no sensitivity to this extract.

When we used the ethyl acetate extract of Ipomoea pes-caprae root (Fig. 2c), the statistically significant difference was observed between the zones of inhibition of the treated and the control wells. In case of Salmonella typhi, Shigella dysenteriae, Salmonella typhi para A, Shigella dysenteriae, Citrobacter species, Staphylococcus saprophyticus, Staphylococcus epidermidis and Streptococcus fecalis, significant zones were observed (p $<0.001 * * *)$. Non-significant zones appeared in case of Proteus mirabilis, Pseudomonas aeruginosa and Enterobacter species and no zone was observed at any concentration in case of Klebsiella pneumoniae and Escherichia coli.

Methanol extract of Ipomoea pes-caprae root (Fig. 2d) showed significant activity against Salmonella typhi, Pseudomonas aeruginosa, Citrobacter species, Shigella dysenteriae, Staphylococcus saprophyticus, Escherichia coli and Salmonella typhi para A ( p <0.001). This shows that these organisms were significantly sensitive against the methanol extract while Enterobacter species, Streptococcus fecalis, Methicillin-resistant Staphylococcus aureus (MRSA) and Staphylococcus epidermidis were insensitive to the lower concentrations of the extract and showed significant zones at $5000 \mu \mathrm{g}$ concentration only ( $\mathrm{p}<0.001 * * *)$. Only one organism Proteus mirabilis showed nonsignificant zone of inhibition while no effect on Klebsiella pneumoniae.

\section{Discussion:-}

In this study, different solvents were used due to the fact that these organic solvents possess variable polarity for different phyto-compounds. On the basis of number of organisms that showed sensitivity, the order of the inhibitory potential of the stem extracts of Ipomoea pes-caprae against the clinical bacterial isolates was observed as ethylacetate extract $>$ methanol extract > chloroform and hexane extract. Similarly, in case of root extracts of Ipomoea pes-caprae, the order of inhibitory potential was methanol extract $>$ ethyl-acetate extract $>$ hexane extract $>$ chloroform extract.

Collectively, the results shown in Table. 1 demonstrate that the methanol extract of roots and the ethyl acetate extract of stem were more effective against all the tested clinical bacterial isolates as maximum number of bacteria showed susceptibility against these extracts. However, considerable larger zones of inhibition were observed in case of hexane and chloroform extracts of stem. Among our tested clinical isolates, Salmonella typhi, Proteus mirabilis, Pseudomonas aeruginosa, Citrobacter species, and Salmonella typhi para A showed sensitivity to all the extracts of Ipomoea pes-caprae whereas Escherichia coli and Streptococcus fecalis showed sensitivity to the least number of extracts. In this view, chloroform extract of stem was able to produce the largest zone of inhibition of diameter $26 \mathrm{~mm}$ in Salmonella typhi para A. On the other hand, same extract produced smallest zone of inhibition in case of Methicillin-resistant Staphylococcus aureus (MRSA).

The antibacterial activity of these extracts might be due to the compounds like pes-caprein, sterols and other phytochemicals which can be dissolved in various organic solvents. The lower inhibitory potential of some extracts might be due to the fact that some compounds are volatile in nature or get denatured in in-vitro. On the other hand, it might be possible that some organisms did not allow the entrance of the extract inside the cell or those bacteria were insensitive to a particular compound present in that extract (Gull et al., 2012). 


\section{Conclusion:-}

Our results demonstrate that the chloroform and ethyl acetate extracts of stem of Ipomoea pes-caprae and methanolic extract of roots of Ipomoea pes-caprae showed strong inhibitory action against almost all tested clinical isolates. The present study may provide an evidence of the therapeutic potential of Ipomoea pes-caprae. Our results support the use of the aforementioned plant against Salmonella typhi, Proteus mirabilis, Pseudomonas aeruginosa, Citrobacter species and Salmonella typhi para A infections.

Table I:-Highest zone of inhibition ( $\mathrm{mm}$ ) against different clinical bacterial isolates at variable Extracts' concentrations

\begin{tabular}{|c|c|c|c|c|c|c|c|c|}
\hline \multirow[b]{2}{*}{ Clinical Isolates } & \multicolumn{4}{|c|}{$\begin{array}{l}\text { Ipomoea pes-caprae STEM } \\
\text { (zone of inhibition, in mm) }\end{array}$} & \multicolumn{4}{|c|}{$\begin{array}{l}\text { Ipomoea pes-caprae ROOT } \\
\text { (zone of inhibition, in mm) }\end{array}$} \\
\hline & $\begin{array}{l}\text { Hexane } \\
\text { Extract }\end{array}$ & $\begin{array}{l}\text { Chloroform } \\
\text { Extract }\end{array}$ & $\begin{array}{l}\text { Ethyl } \\
\text { acetate } \\
\text { Extract }\end{array}$ & $\begin{array}{l}\text { Methanol } \\
\text { Extract }\end{array}$ & $\begin{array}{l}\text { Hexane } \\
\text { Extract }\end{array}$ & $\begin{array}{l}\text { Chloroform } \\
\text { Extract }\end{array}$ & $\begin{array}{l}\text { Ethyl } \\
\text { acetate } \\
\text { Extract }\end{array}$ & $\begin{array}{l}\text { Methanol } \\
\text { Extract }\end{array}$ \\
\hline Salmonella typhi & 18 & 12 & 16 & 14 & 11 & 14 & 14 & 15 \\
\hline $\begin{array}{l}\text { Proteus } \\
\text { mirabilis }\end{array}$ & 14 & 15 & 13 & 9 & 18 & 14 & 8 & 15 \\
\hline $\begin{array}{l}\text { Pseudomonas } \\
\text { aeruginosa }\end{array}$ & 16 & 17 & 13 & 13 & 12 & 0 & 12 & 12 \\
\hline $\begin{array}{l}\text { Citrobacter } \\
\text { species }\end{array}$ & 15 & 21 & 14 & 14 & 13 & 12 & 12 & 12 \\
\hline $\begin{array}{l}\text { Enterobacter } \\
\text { species }\end{array}$ & 13 & 15 & 12 & 12 & 12 & 0 & 13 & 12 \\
\hline $\begin{array}{l}\text { Klebsiella } \\
\text { pneumoniae }\end{array}$ & 12 & 15 & 12 & 13 & 12 & 0 & 0 & 0 \\
\hline $\begin{array}{l}\text { Salmonella typhi } \\
\text { para A }\end{array}$ & 18 & 26 & 15 & 11 & 12 & 12 & 14 & 13 \\
\hline $\begin{array}{l}\text { Staphylococcus } \\
\text { saprophyticus }\end{array}$ & 14 & 16 & 8 & 18 & 0 & 0 & 14 & 15 \\
\hline $\begin{array}{l}\text { Methicillin } \\
\text { Resistant } \\
\text { Staphylococcus } \\
\text { aureus (MRSA) }\end{array}$ & 18 & 8 & 12 & 11 & 0 & 0 & 15 & 13 \\
\hline $\begin{array}{l}\text { Staphylococcus } \\
\text { epidermidis }\end{array}$ & 15 & 0 & 15 & 8 & 0 & 0 & 13 & 15 \\
\hline Escherichia coli & 0 & 0 & 11 & 0 & 0 & 0 & 0 & 13 \\
\hline $\begin{array}{l}\text { Streptococcus } \\
\text { fecalis }\end{array}$ & 0 & 0 & 0 & 0 & 0 & 0 & 13 & 13 \\
\hline $\begin{array}{l}\text { Shigella } \\
\text { dysenteriae }\end{array}$ & 0 & 14 & 13 & 15 & 0 & 0 & 13 & 12 \\
\hline
\end{tabular}

Fig 1:-Bactericidal effects of Ipomoea pes-caprae stem extracts

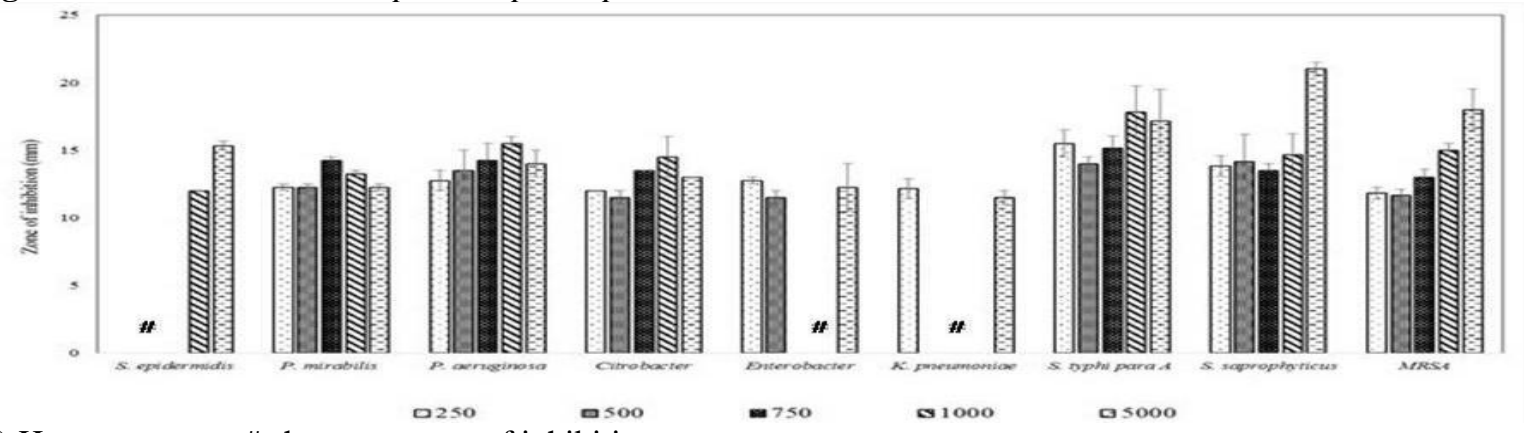

(a) Hexane extract, \# shows no zone of inhibition 


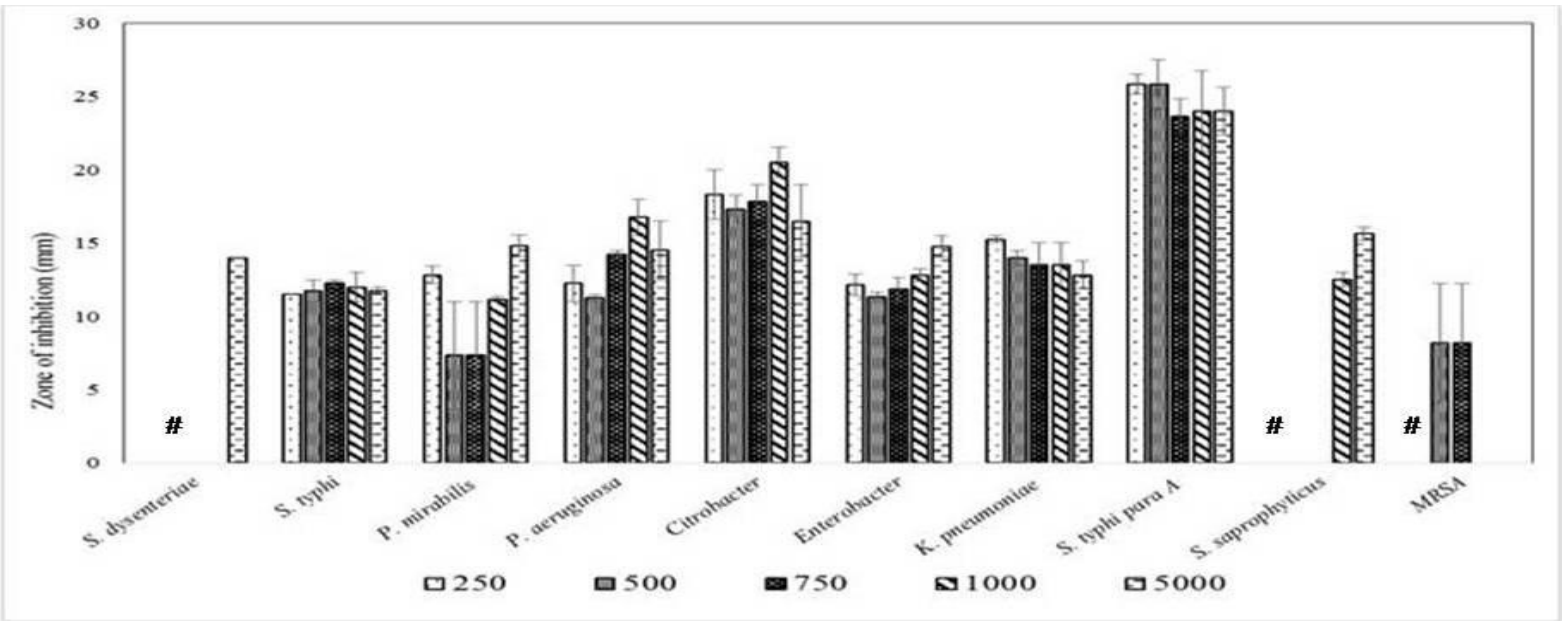

(b) Chloroform extract, \# shows no zone of inhibition

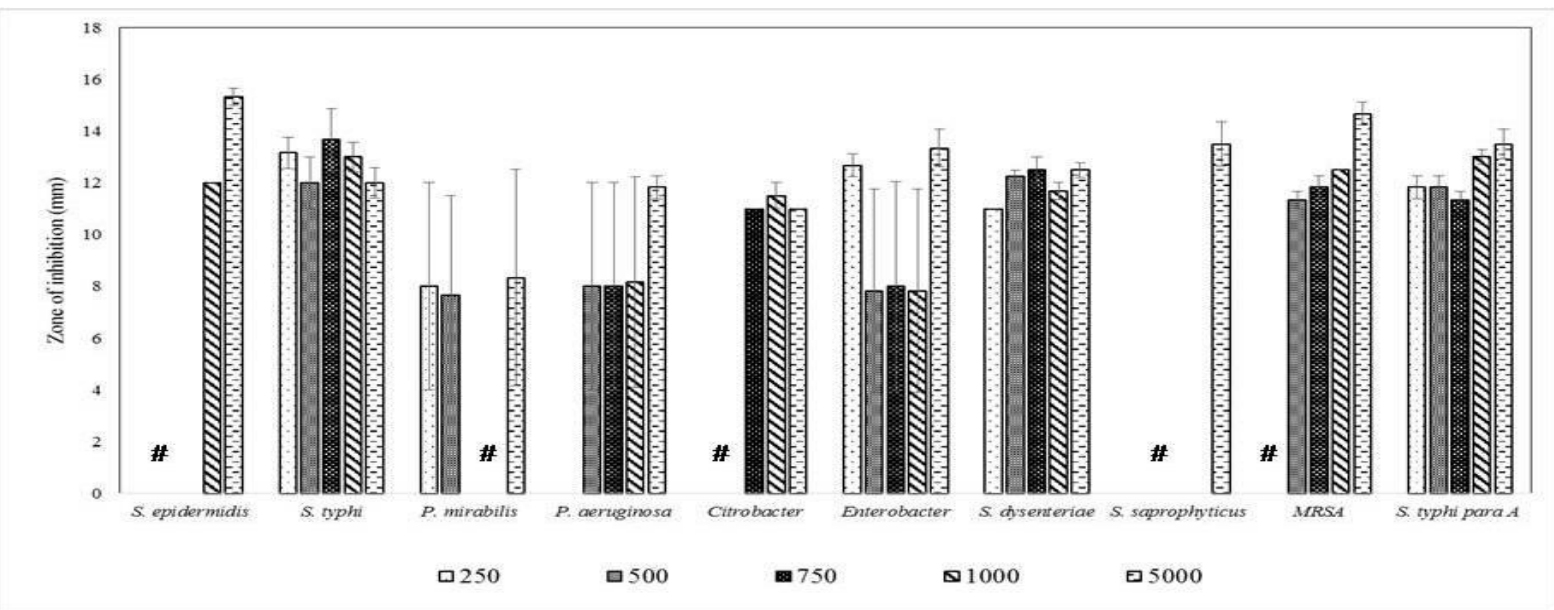

(c) Ethyl acetate extract, \# shows no zone of inhibition

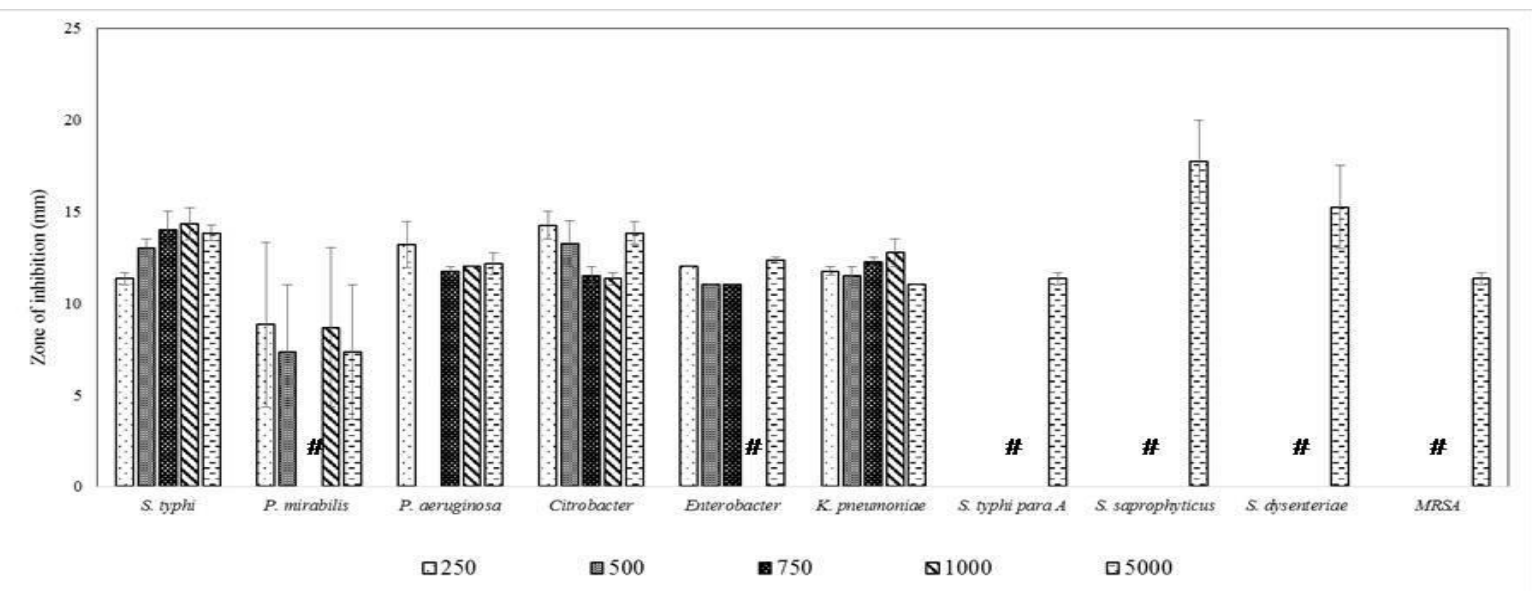

(d) Methanol extract, \# shows no zone of inhibition 
Fig 2:-Bactericidal effects of Ipomoea pes-caprae root extracts

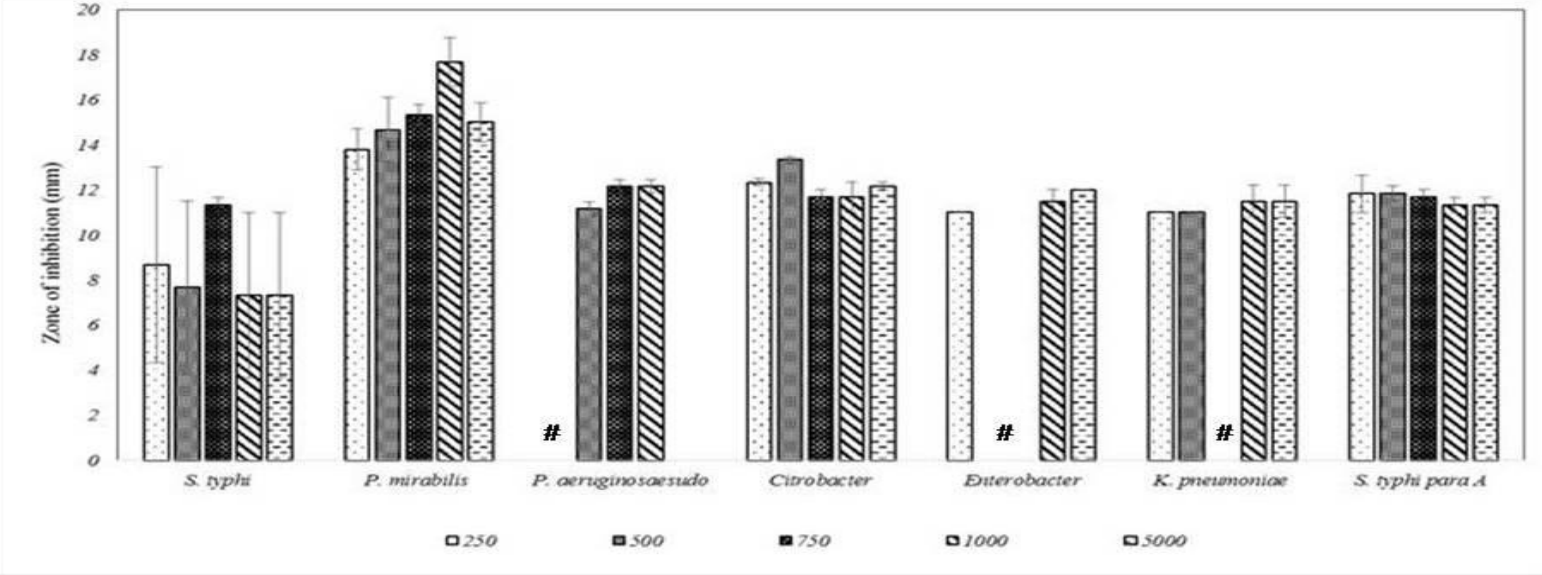

(a) Hexane extract, \# shows no zone of inhibition

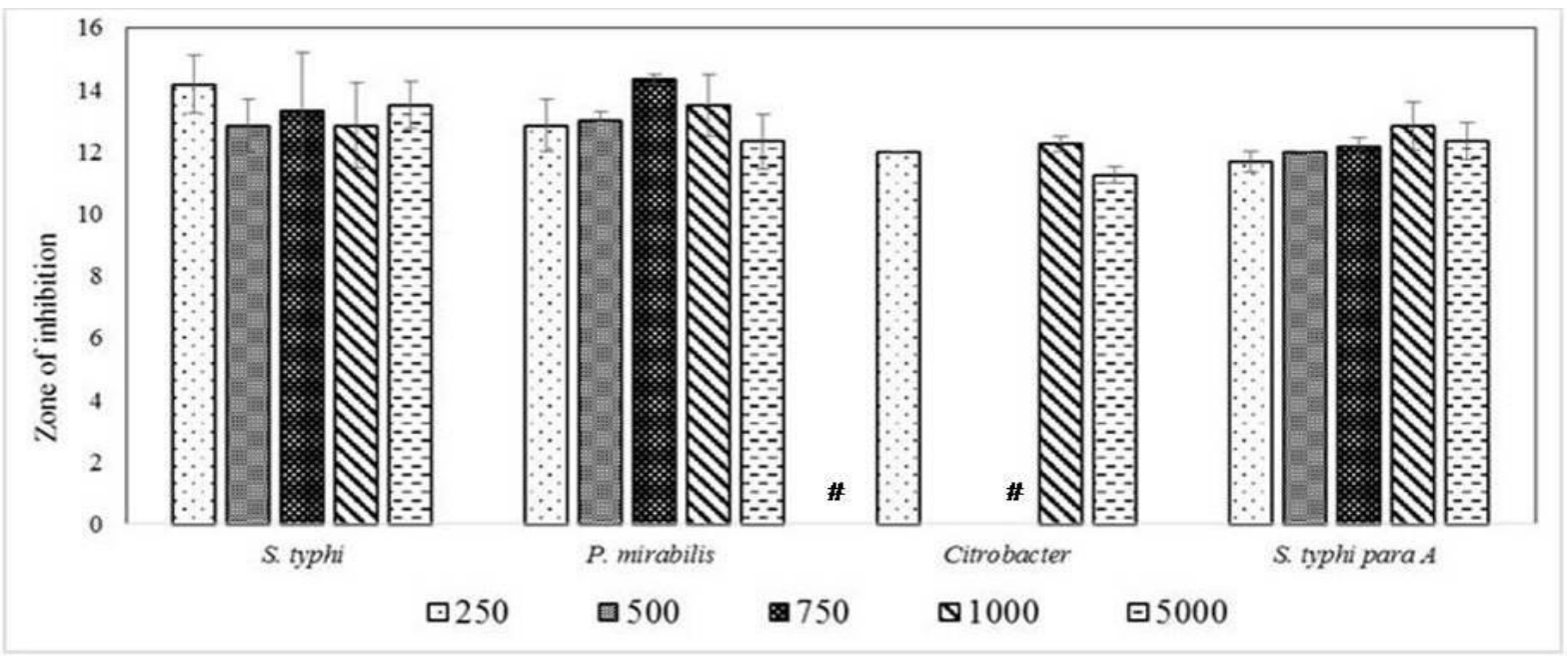

(b) Chloroform extract, \# shows no zone of inhibition

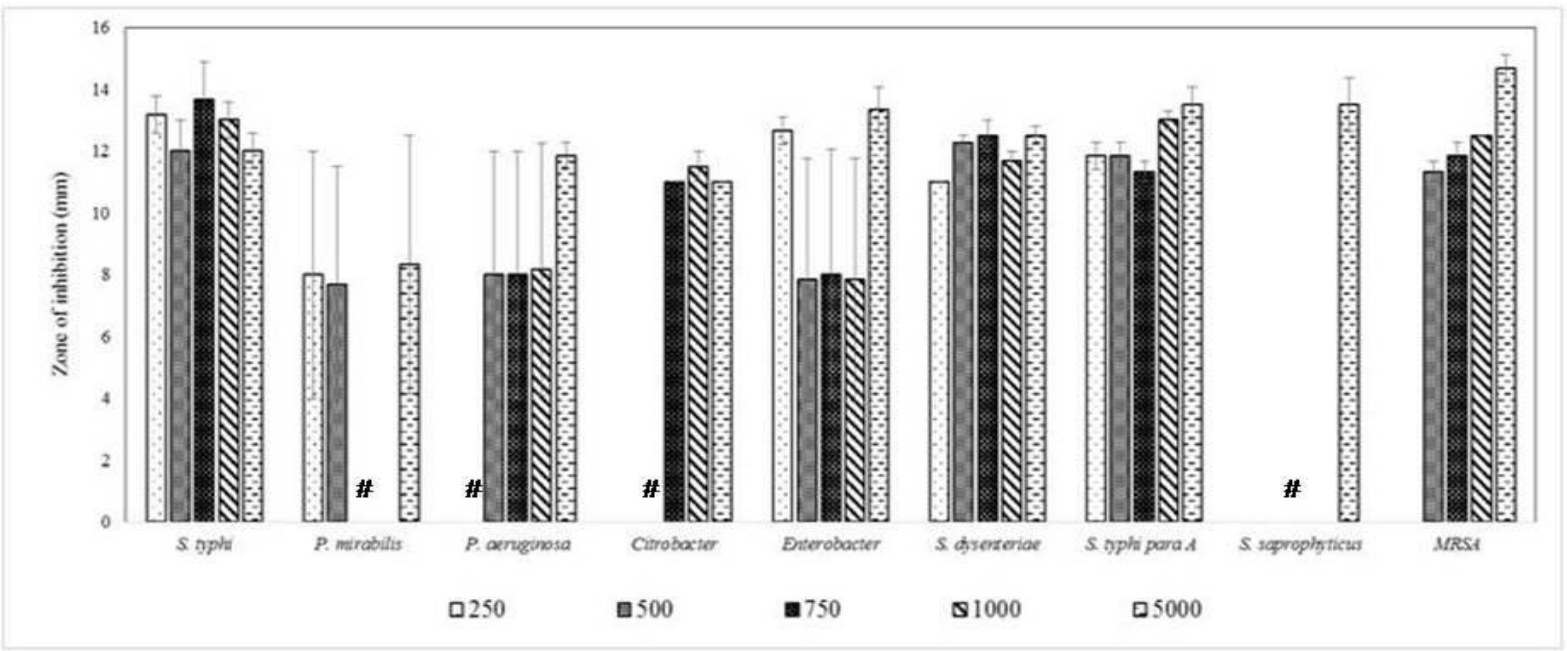

(c) Ethyl acetate extract, \# shows no zone of inhibition 


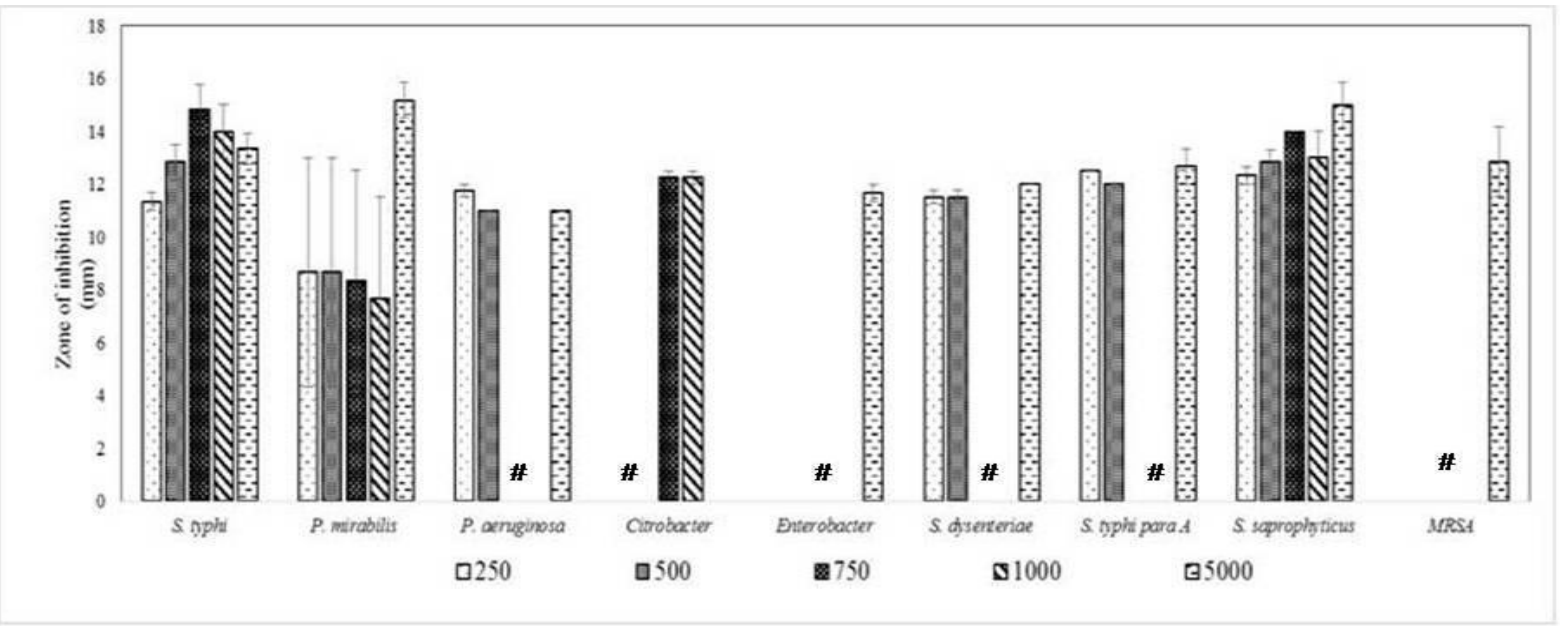

(d) Methanol extract, \# shows no zone of inhibition

\section{References:-}

1. Aruna, D. S. and Nandakishore, D. L. V. (2014): Haritaki a boon to herbalism - a review. Scholars Academic Journal of Biosciences, 2: 132-136.

2. Austin, D.F. and Ghazanfar, S. (1979): Convolvulaceae. Flora of Pakistan, 126: 46.

3. Bahashwan, S.A. and El Shafey, H.M. (2013): Antimicrobial Resistance patterns of Proteus isolates from clinical specimens. European Scientific Journal, 9: 188-202.

4. Chao, S., Young, G., Oberg, C. and Nakaoka, K. (2008): Inhibition of methicillin-resistant Staphylococcus aureus (MRSA) by essential oils. Flavour and Fragrance Journal, 23: 444-449.

5. Coyle, M. B. (2005). Manual of antimicrobial susceptibility testing. American Society for Microbiology.

6. Dave, S. B., Toma, H. S. and Kim, S. J. (2011): Ophthalmic Antibiotic Use and Multidrug- Resistant Staphylococcus epidermidis. Ophthalmology, 118: 2035-2040.

7. Debarbieux, L., Leduc, D., Maura, D., Morello, E., Criscuolo, A., Grossi, O., Balloy, V. and Touqu, L. (2010): Bacteriophages can Treat and Prevent Pseudomonas aeruginosa Lung Infections. The Journal of Infectious Diseases, 201: 1096-1104.

8. Gull, I., Saeed, M., Shaukat, H., Aslam, S. M., Samra, Z. Q. and Athar, A. M. (2012): Inhibitory effect of Allium sativum and Zingiber officinale extracts on clinically important drug resistant pathogenic bacteria. Annals of clinical microbiology and antimicrobials, 11: 8.

9. Jayaraj, M., Villaluz, J. E., Seth, M. and Cronin (2014): Emerging Infectious Liver Disease -Metastasizing Klebsiella pneumoniae Liver Abscess. The Journal of Lipid Research, 3: 151-152.

10. Kariuki, S., Revathi, G., Corkill, J., Kiiru, J., Mwituria, J., Mirza, N. and Hart C. A. (2007): Escherichia coli from community-acquired urinary tract infections resistant to fluoroquinolones and extended-spectrum betalactams. The Journal of Infection in Developing Countries, 1: 257-262.

11. Kayaoglu, G. and Orstavik, D. (2004): Virulence factors of Enterococcus faecalis: relationship to endodontic disease. Critical Reviews in Oral Biology \& Medicine, 15: 308-320.

12. Khan, R., Islam, B., Akram, M., Shakil, S., Ahmad, A., Manazir, S. A., Siddiqui, M. and Khan, A.U. (2009): Antimicrobial activity of five herbal extracts against multi drug resistant (MDR) strains of bacteria and fungus of clinical origin. Molecules, 14: 586-597.

13. Kumar, N., Das, S., Jyoti, A. and Kaushik, S. (2016): Synergistic effect of silver nanoparticles with doxycycline against Klebsiella pneumonia. International journal of Pharmacy and Pharmaceutical Sciences, 8:183-186.

14. Modak, M., Dixit, P., Londhe, J., Ghaskadbi, S. and Devasagayam, P.A. (2007): Indian herbs and herbal drugs used for the treatment of diabetes. J. Clin. Biochem. Nutr.,40: 163-73.

15. Naveed, A. and Ahmed, Z. (2016): Treatment of Typhoid Fever in Children: Comparison of Efficacy of Ciprofloxacin with Ceftriaxone. European Scientific Journal, 12: 346-355.

16. Omololu-Aso, J., Oluwatoyin, O., Omololu-Aso, Atiene, M. T., Adejuwon A., Owolabi, A. T. and Shesha, A. (2017): Salmonellosis and Shigellosis Associated with Cattle Dung Contaminant from Indigenous Abattoirs, Osun State, Nigeria. British Journal of Research, 4:1-4. 
17. Parasa, L. S, Tumati, S. R., Chigurupati, S. P., Parabathina, R. K. and Santhisree, K. (2011): Prevalence of induced clindamycin resistance in methicillin resistant Staphylococcus aureus from hospital population of coastal Andhara Pradesh, South India. Archieves of Clinical Microbiology, 2: 1-6.

18. Raz, R., Colodner, R. and Kunin, C. M. (2005): Staphylococcus saprophyticus. Clinical Infectious Diseases, 40: 896-898.

19. Redfern, J., Kinninmonth, M., Burdass, D. and Verran, J. (2014): Using soxhlet ethanol extraction to produce and test plant material (essential oils) for their antimicrobial properties. Journal of microbiology \& biology education, 15: 45-46.

20. Saleh, F., Ahmed, H. A., Khairy, R. M. M. and Abdelwahab, S. F. (2014): Increased quinolone resistance among typhoid Salmonella isolated from Egyptian patients. Journal of Infection in Developing Countries, 8: 661-665.

21. Sharma, B., Balomajumder, C. and Roy, P. (2008): Hypoglycemic and hypolipidemic effects of flavonoid rich extract from Eugenia jambolana seeds on streptozotocin induced diabetic rats. Food and Chemical Toxicology, 46: $2376-2383$.

22. Tiwari, A.K. and Raos, J.M. (2002): Diabetes mellitus and multiple therapeutic approaches of phytochemicals: Present status and future prospects. Current Science, 83: 30-38.

23. Widerstrom, M., Wistrom, J., Sjostedt, A. and Monsen, T. (2012): Coagulase-negative staphylococci: update on the molecular epidemiology and clinical presentation, with a focus on Staphylococcus epidermidis and Staphylococcus saprophyticus. European Journal of Clinical and Microbiol Infectious Diseases, 31: 7-20. 